\title{
Impact of iron deficiency anemia on HbA1c level in non-diabetic children
}

\begin{tabular}{cc}
\hline Mohammed Hamad Ameen Qader ${ }^{1 *}$ & Abbas Abdulkadir Rabaty $^{2}$ \\
\hline Abstract &
\end{tabular}

Background and objective: $\mathrm{HbA} 1 \mathrm{c}$ has been endorsed by the American Diabetes Association and World Health Organization to diagnose and monitor diabetes mellitus. Its value is directly proportional to the blood glucose level. However, besides the blood glucose level, other factors like iron deficiency anemia can affect $\mathrm{HbA1c}$ level. We conducted this study to reveal the impact of iron deficiency anemia on $\mathrm{HbA1c}$ level and to assess whether $\mathrm{HbA} 1 \mathrm{c}$ result changes after the correction of iron deficiency anemia.

Methods: Twenty five non-diabetic children who were confirmed to have iron deficiency anemia were enrolled. HbA1c, hemoglobin, serum iron, and ferritin were measured and compared at baseline and post-correction of iron deficiency anemia with a three-month age-appropriate dose of iron therapy. The baseline results were compared with 25 age- and sex-matched normal controls.

Results: Children with iron deficiency anemia had significantly higher $\mathrm{HbA} 1 \mathrm{c}$ level $(6.144 \pm 0.6312, P<0.001)$ than the control group $(5.032 \pm 0.5558, P<0.001)$. After three months of treatment of iron deficiency anemia, $\mathrm{HbA} 1 \mathrm{c}$ significantly dropped (from $6.144 \pm 0.6312, P<0.001$ to $5.604 \pm 0.51, P<0.001)$.

Conclusion: This study concluded that $\mathrm{HbA} 1 \mathrm{c}$ is inversely proportional to iron deficiency anemia in non-diabetic children, and treatment of iron deficiency anemia led to a drop in $\mathrm{HbA} 1 \mathrm{c}$ level. Due to this false elevation of $\mathrm{HbA} 1 \mathrm{c}$ by iron deficiency anemia, iron deficiency anemia should be considered and excluded before making the diagnosis or deciding on any therapeutic change in diabetic children.

Keywords: Iron deficiency anemia; HbA1c; Non-diabetic children.

\section{Introduction}

$\mathrm{HbA} 1 \mathrm{c}$ or glycated hemoglobin is formed by the attachment of glucose to the hemoglobin inside erythrocytes. HbA1c test measures the amount of blood glucose attached to hemoglobin in red blood cells over the past three months related to the lifespan of red blood cells, which is about 120 days. ${ }^{1,2} \mathrm{HbA} 1 \mathrm{c}$ is directly proportional to good glycemic control. One of the primary goals in the management of diabetic patients is to have good glycemic control to decrease the potentiality of diabetes-related complications. ${ }^{3,4}$ Since 2010, both American Diabetes Association and World Health Organization have endorsed the $\mathrm{HbA} 1 \mathrm{c}$ test as a diagnostic tool for diabetes mellitus. Levels below $5.7 \%$ are normal, values of $5.7 \%-6.5 \%$ are suggestive of pre-diabetes, and any results equal to or above $6.5 \%$ establish the diagnosis of diabetes mellitus. ${ }^{5-7}$ However, it is not only the glucose level that affects the $\mathrm{HbA} 1 \mathrm{c}$ test. It will be influenced by hemolytic anemia, hemoglobinopathies, acute and chronic blood loss, and uremia. Furthermore, vitamin B12, folate, and iron deficiency anemia (IDA) have also been shown to alter $\mathrm{HbA} 1 \mathrm{c}$ level. . $^{8-14}$

Iron deficiency is the commonest nutritional deficiency worldwide and is a major public health issue globally. ${ }^{15}$ According to the World Health Organization, IDA affects about $30 \%$ of the global population and is

${ }^{1}$ Raparin Pediatric Hospital, Erbil, I raq

2 Department of Pediatrics, College of Medicine, Hawler Medical University, Erbil, I raq.

* Correspondence: muhemet@gmail.com 
more prevalent among children in developing countries. ${ }^{16}$ The most common type of anemia in children is microcytic anemia due to iron deficiency. ${ }^{17}$ Hemoglobin values two standard deviations below the mean for age and sex are regarded as anemia. The cutoff level of hemoglobin to decide on having anemia for children aged 6-59 months is $11 \mathrm{~g} / \mathrm{dl}$, for $5-11$ years is $11.5 \mathrm{~g} / \mathrm{dl}$, and it is $12 \mathrm{~g} / \mathrm{dl}$ for 12-14 years. $^{18-20}$ IDA decelerates erythrocyte turnover leading to increased mean survival of erythrocytes which affects glycation of hemoglobin and thereby might alter $\mathrm{HbA} 1 \mathrm{c}$ level. ${ }^{13}$ There is no consensus on how IDA affects $\mathrm{HbA1c}$ value. Studies done by Brooks et al. and Sluiter et al. found out an elevation of $\mathrm{HbA} 1 \mathrm{c}$ level in IDA. On the other hand, Heyningen et al. and Hansen et al. revealed that IDA exerts no impact on HbA1c level. ${ }^{8-14}$ Furthermore, a study by Nitin Sinha, et al. reported that $\mathrm{HbA} 1 \mathrm{c}$ level increased after treatment of IDA with iron therapy. ${ }^{10}$

The results from these studies are inconsistent about the relation between IDA and $\mathrm{HbA} 1 \mathrm{c}$ level. Therefore, we conducted this study to determine the influence of IDA on the HbA1c level. This study aimed to measure HbA1c level in non-diabetic children with IDA, assess the effect of IDA on $\mathrm{HbA} 1 \mathrm{c}$ level, and see whether $\mathrm{HbA} 1 \mathrm{c}$ level is altered after correcting IDA.

\section{Methods}

This non-randomized controlled trial (quasi-experimental) study has been carried out at Raparin Pediatric Hospital and Nanakaly hospital for hematological and oncological diseases in Erbil city, Kurdistan Region, Iraq, over six months from November 1, 2019, to May 1, 2020. The data involved in this study were taken from two groups. Group A (study group) consisted of 25 children who had IDA and group B (control group), who were 25 children but had no IDA. Children from group $B$ were matched for the same age and sex with group A. Inclusion criterion for the study group was any non-diabetic children below the age of 18 years who had IDA. Children who had a history of diabetes mellitus or had fasting blood glucose $>100 \mathrm{mg} / \mathrm{dl}$ even in the absence of a history of established diabetes mellitus were excluded from this study. Other exclusion criteria were anemia other than IDA, those with acute febrile illness, and children who had any chronic illness. Participants from both groups, after fulfilling the inclusion criteria, were enrolled in the study. All of them were subjected to a full history taking and thorough physical examination. The following investigations: complete blood count to measure hemoglobin $(\mathrm{gm} / \mathrm{dl})$, mean corpuscular volume (80-100 fl) and mean corpuscular hemoglobin (25.4-36.4 pg/cell), ${ }^{21}$ serum ferritin (12-300ng/mL), serum iron (60-170 $\mathrm{mcg} / \mathrm{dl}),{ }^{22}$ and HbA1c level had been done for group $A$ both at baseline and three months after treatment of IDA with weight appropriate dose of iron therapy at a dose of $3-6 \mathrm{mg} / \mathrm{kg}$ of elemental iron for three months duration. ${ }^{16}$ The same investigations were done for the control group once at baseline. The baseline results of $\mathrm{HbA} 1 \mathrm{c}$ level in IDA group (group A) were compared with that of group B. Likewise, the baseline and at three months (post-correction of IDA) $\mathrm{HbA1c}$ level results of group $A$ were compared with each other to observe any potential change in $\mathrm{HbA1c}$ level after IDA had been corrected.

\section{Laboratory tests}

Fasting blood glucose level was checked using (Accu-Check ${ }^{\circledR}$ Active Model: GU, Ser. No. GU03560779 Roche Germany) glucometer. Complete blood count was performed with Medonic M-series (Boule Medical AB, Stockholm, Sweden). Serum ferritin and serum iron were determined by COBAS INTEGRA 400/800 Chemistry analyzer. HbA1c value was measured by Gesan 400 device (Gesan production S.r.1. Campobello di Mazara, Italy). All the investigations were done with the same devices using the same methods throughout the study. 


\section{Ethical consideration}

The ethical approval of this study was granted by the Research Ethics Committee of the Kurdistan Board of Medical Specialties before conducting the study. Informed consent (both verbal and written) was obtained from parents of enrolled children.

\section{Data analysis}

The data were recorded on a specially designed questionnaire, collected and entered in the computer via Microsoft Excel worksheet (Excel 2010) and then analyzed using the statistical package for the social sciences, version 24 (SPSS, IBM Company, Chicago, USA). Pearson correlation coefficient $(r)$ was calculated to assess the correlation between two numerical variables. Paired student $t$-test was applied to compare variables among the study group before and after treatment. The independent samples $t$-test was used to compare variables between study and comparison groups. $A P$ value of $<0.05$ was considered statistically significant.

\section{Results}

A total of 50 children were enrolled in the current study. They were divided equally into two groups -case and control - each of 25 children. The two groups were matched for gender (14 males and 11 females) and age (mean \pm SD of $2.104 \pm 0.95$ years), $60 \%$ of the children were from urban settings, and $40 \%$ were from rural areas.

The findings from Table 1 illustrate a statistically significant difference in all measures between case and control groups. At the start of the study, the average baseline readings, including $\mathrm{Hb}$, $\mathrm{MCH}, \mathrm{MCV}$, serum iron, and ferritin, were higher among the control group in comparison to cases, except for $\mathrm{HbA} 1 \mathrm{c}$, which was lower in the control group compared to the study group participants. $T$-test was performed to compare the averages of the two groups, and $P$ values were less than 0.05 .

Table 1 Comparison between case and control groups regarding hematological indices

\begin{tabular}{llcccc}
\hline Variables & Study group & N & Mean & $( \pm$ SD) & $P$ value \\
\hline Hb baseline & Group A & 25 & 9.47 & $( \pm 1.05)$ & $<0.001$ \\
& Group B & 25 & 12.56 & $( \pm 0.84)$ & \\
MCV baseline & Group A & 25 & 60.44 & $( \pm 4.71)$ & $<0.001$ \\
& Group B & 25 & 85.00 & $( \pm 6.37)$ & \\
MCH baseline & Group A & 25 & 19.40 & $( \pm 2.55)$ & $<0.001$ \\
& Group B & 25 & 28.00 & $( \pm 1.65)$ & \\
Serum iron baseline & Group A & 25 & 29.84 & $( \pm 10.15)$ & $<0.001$ \\
& Group B & 25 & 82.80 & $( \pm 17.45)$ & \\
Serum ferritin baseline & Group A & 25 & 10.04 & $( \pm 2.50)$ & $<0.001$ \\
& Group B & 25 & 140.72 & $( \pm 81.26)$ & \\
HbA1c baseline & Group A & 25 & 6.14 & $( \pm 0.63)$ & $<0.001$ \\
& Group B & 25 & 5.03 & $( \pm 0.55)$ & \\
\hline
\end{tabular}


The results of Table 2 reveal a significant statistical difference in hematological measures of cases before and after receiving the treatment. Generally, all hematological indices increased after three months of receiving treatment for IDA. The only measure that decreased after treatment was $\mathrm{HbA} 1 \mathrm{c}$. All these differences were statistically significant. The mean $\mathrm{Hb}$ at the start was $9.47 \mathrm{gm} / \mathrm{dl}$, which increased to $12.72 \mathrm{gm} / \mathrm{dl}$ after therapy. The $\mathrm{MCV}$ at baseline was $60.44 \mathrm{fl}$, then became higher after three months to reach $80.44 \mathrm{fl}$. Similarly, $\mathrm{MCH}$ rose from $19.40 \mathrm{pg} / \mathrm{cell}$ to $26.88 \mathrm{pg} / \mathrm{cell}$ upon completion of therapy. The serum iron also increased dramatically from $29.84 \mathrm{mcg} / \mathrm{dl}$ to $82.00 \mathrm{mcg} / \mathrm{dl}$. The serum ferritin at the baseline was $10.04 \mathrm{ng} /$ $\mathrm{mL}$, which also increased to a great extent to reach $98.76 \mathrm{ng} / \mathrm{mL}$. The only measurement that decreased was $\mathrm{HbA} 1 \mathrm{c}$; it was $6.14 \%$ originally, then dropped to $5.60 \%$. Paired $t$-test was done to compare the average readings of the two occasions, and in all conditions, the $P$ value was $<0.001$.

As depicted in Figure 1, there was a significant inverse correlation between $\mathrm{HbA} 1 \mathrm{c}$ reading and serum ferritin level (r: -0.494 and $P<0.001$ ), with an increase in serum ferritin level, HbA1c dropped.

Table 2 Difference in hematological measures before and after treatment

\begin{tabular}{|c|c|c|c|c|}
\hline Variables & $\mathbf{N}$ & Mean & (士SD) & $P$ value \\
\hline Hb baseline & 25 & 9.47 & $( \pm 1.05)$ & $<0.001$ \\
\hline Hb 3 months & 25 & 12.72 & $( \pm 0.87)$ & \\
\hline MCV baseline & 25 & 60.44 & $( \pm 4.71)$ & $<0.001$ \\
\hline MCV 3 months & 25 & 80.44 & $( \pm 6.90)$ & \\
\hline $\mathrm{MCH}$ baseline & 25 & 19.40 & $( \pm 2.55)$ & $<0.001$ \\
\hline $\mathrm{MCH} 3$ months & 25 & 26.88 & $( \pm 1.92)$ & \\
\hline S. Iron baseline & 25 & 29.84 & $( \pm 10.15)$ & $<0.001$ \\
\hline S. Iron 3 months & 25 & 82.00 & $( \pm 14.56)$ & \\
\hline S. Ferritin baseline & 25 & 10.04 & $( \pm 2.51)$ & $<0.001$ \\
\hline S. Ferritin 3 months & 25 & 98.76 & $( \pm 62.51)$ & \\
\hline $\mathrm{HbA} 1 \mathrm{c}$ baseline & 25 & 6.14 & $( \pm 0.63)$ & $<0.001$ \\
\hline HbA1c 3 months & 25 & 5.60 & $( \pm 0.51)$ & \\
\hline
\end{tabular}

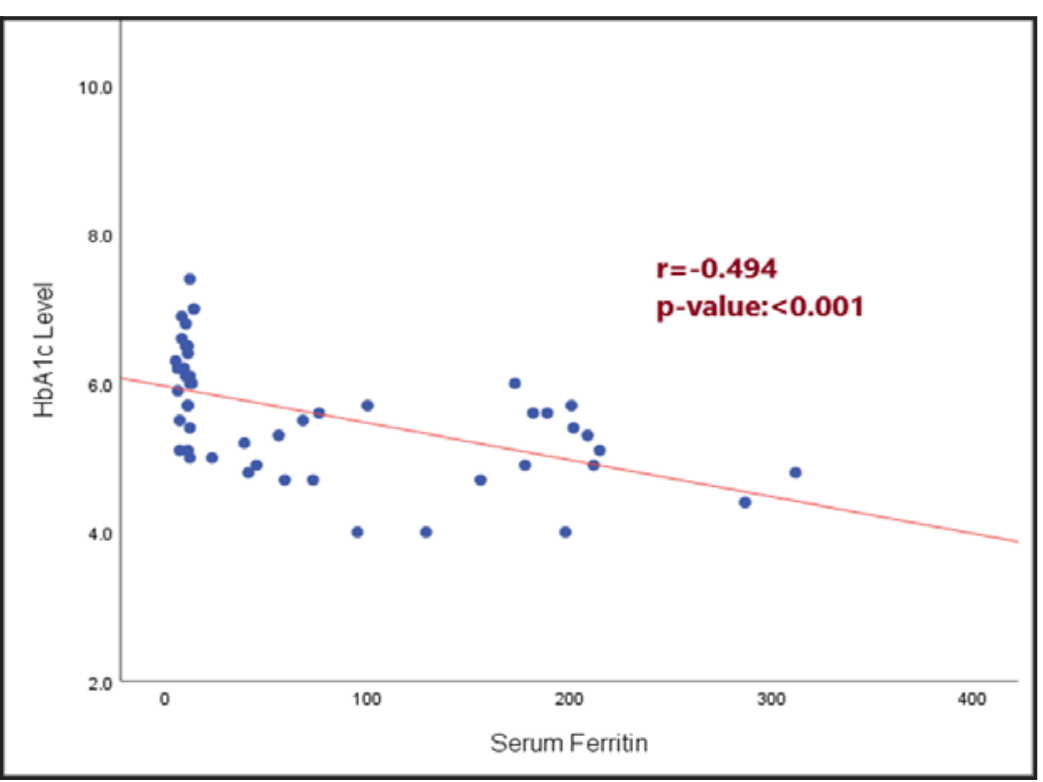

Figure 1 Correlation between $\mathrm{HbA} 1 \mathrm{c}$ level and serum ferritin level 


\section{Discussion}

$\mathrm{HbA1c}$ test has been accepted as a screening tool to diagnose diabetes mellitus and as a marker of glycemic control as it is affected by blood glucose level. ${ }^{12}$ However, besides blood glucose, various other factors like physiological, genetic, and hematological factors may alter $\mathrm{HbA} 1 \mathrm{c}$ value. ${ }^{23}$ Anemia including IDA may falsely increase or decrease $\mathrm{HbA1c}$ value depending on the type of anemia. Multiple studies have been done to know the effect of IDA on the HbA1c level. The results were contradictory.

In this study, we observed that $\mathrm{HbA} 1 \mathrm{c}$ levels were significantly higher in nondiabetic children who had IDA compared to $\mathrm{HbA} 1 \mathrm{c}$ levels of age- and sex-matched children who were free from IDA $(P<0.001)$. We treated the IDA group with an age-appropriate dose of iron therapy for three months. Then we compared pre- and post-IDA HbA1c measurements among the IDA group. We noticed that with the increase of hemoglobin and serum ferritin, the $\mathrm{HbA} 1 \mathrm{c}$ level significantly dropped $(P<0.001)$.

The results of our study are similar to the results of many other studies like Christy et al. and Rajagopal et al. that revealed $\mathrm{HbA} 1 \mathrm{c}$ levels were higher among the IDA group, and the level decreased significantly after treatment and correction of IDA. ${ }^{11,14}$ This study results are also consistent with studies done by Bhardwaj et al. and Hong et al., ${ }^{10,13}$ who reported an inverse correlation between $\mathrm{HbA} 1 \mathrm{c}$ level and IDA and a decline in HbaA1c level following correction of anemia due to iron deficiency. The exact mechanism of how IDA exerts its effect on $\mathrm{HbA} 1 \mathrm{c}$ remains unclear. It has been speculated that the quaternary structure of the $\mathrm{Hb}$ molecule may be changed, and glycation of beta-globin chain occurs more easily in the relative absence of iron. Another reason that has been proposed is that glycation of $\mathrm{Hb}$ is an irreversible process, and therefore, the concentration of $\mathrm{HbA} 1$ in one erythrocyte will increase linearly with the cell's age. ${ }^{10}$
The results of some studies contradict this study's results. Solomon et al. found that the $\mathrm{HbA} 1 \mathrm{c}$ result is significantly lower in IDA patients than non-IDA diabetic patients. ${ }^{12}$ In contrast to what we observed, Sinha et al. concluded that treatment and correction of IDA led to an increase in $\mathrm{HbA1c}$ level. They suggested that lower $\mathrm{HbA} 1 \mathrm{c}$ is due to the severity of anemia in the study participants. ${ }^{24}$

Limitations to this study included enrolling a small number of children, and including only two hospitals in Erbil city. Studies involving larger populations of children and in multiple centers needed to be conducted to better reveal the influence of IDA on $\mathrm{HbA} 1 \mathrm{c}$ modulation.

\section{Conclusion}

In this study, we concluded that $\mathrm{HbA1c}$ is inversely proportional to IDA in nondiabetic children, and treatment of IDA led to a drop in $\mathrm{HbA} 1 \mathrm{c}$ level. The false elevation of $\mathrm{HbA} 1 \mathrm{c}$ level in IDA children independent of blood glucose level should make physicians and health care providers not depend solely on $\mathrm{HbA} 1 \mathrm{c}$ value both for diagnosis or monitoring of diabetic patients. Hence, IDA should be considered and excluded before making the diagnosis or deciding on any therapeutic change in diabetic children.

\section{Funding}

None.

\section{Competing interests}

None declared.

\section{References}

1. Lin $\mathrm{H}, \mathrm{Yi} J$. Current status of $\mathrm{HbA} 1 \mathrm{c}$ biosensors. Sensors (Basel). 2017; 17(8):1798. https://doi.org/10.3390/s17081798.

2. Ohde S, Deshpande GA, Yokomichi H, Takahashi $\mathrm{O}$, Fukui T, Yamagata Z. HbA1c monitoring interval in patients on treatment for stable type 2 diabetes. A ten-year retrospective, open cohort study. Diabetes Res Clin Pract. 2018; 135:16671. https://doi.org/10.1016/j.diabres.2017.11.013.

3. Luo M, Tan KHX, Tan CS, Lim WY, Tai ES, Venkataraman K. Longitudinal trends in $\mathrm{HbA1c}$ patterns and association with outcomes: A systematic review. Diabetes Metab Res 
Rev. 2018; 34(6):e3015. https://doi.org/10.1002/ dmrr.3015.

4. Weykamp C. HbA1c: A review of analytical and clinical aspects. Ann Lab Med. 2013; 33(6):393400. https://doi.org/10.3343/alm.2013.33.6.393.

5. Lim WY, Ma S, Heng D, Tai ES, Khoo CM, Loh TP. Screening for diabetes with $\mathrm{HbA} 1 \mathrm{c}$ : Test performance of $\mathrm{HbA} 1 \mathrm{c}$ compared to fasting plasma glucose among Chinese, Malay and Indian community residents in Singapore. Sci Rep. 2018; 8(1):12419. https://doi.org/10.1038/ s41598-018-29998-z.

6. Li G, Han L, Wang Y, Zhao Y, Li Y, Fu J, et al. Evaluation of ADA $\mathrm{HbA1c}$ criteria in the diagnosis of pre-diabetes and diabetes in a population of Chinese adolescents and young adults at high risk for diabetes: a cross-sectional study. BMJ Open. 2018; 8(8):e020665. https://doi.org/10.1136/bmjopen-2017-020665.

7. American Diabetes A. 2. Classification and Diagnosis of Diabetes: Standards of Medical Care in Diabetes-2018. Diabetes Care. 2018; 41(Suppl 1):S13-27. https://doi.org/10.2337/dc16-er09.

8. Attard SM, Herring $\mathrm{AH}$, Wang $\mathrm{H}$, Howard $A G$, Thompson AL, Adair LS, et al. Implications of iron deficiency/anemia on the classification of diabetes using HbA1c. Nutr Diabetes. 2015; 5:e166. https://doi.org/10.1038/nutd.2015.16.

9. Bader GN. Influence of iron deficiency anemia on HbA1c: A review. Curr Res Diabetes Obes J. 2018; 5(3):555665. https://doi.org/10.19080/crdoj. 2018.05.555665.

10. Bhardwaj K, Sharma SK, Rajpal N, Sachdev A. Effect of iron deficiency anaemia on haemoglobin A1c levels. Ann Clin Lab Res. 2016; 4:4. https://doi.org/10.21767/2386-5180.1000123.

11. Christy AL, Manjrekar PA, Babu RP, Hegde A, Rukmini MS. Influence of iron deficiency anemia on hemoglobin A1c levels in diabetic individuals with controlled plasma glucose levels. Iran Biomed J. 2014; 18(2):88-93. https://doi.org/10.6091/ibj.1257.2014.

12. Solomon A, Hussein M, Negash $M$, Ahmed A, Bekele $F$, Kahase D. Effect of iron deficiency anemia on $\mathrm{HbA} 1 \mathrm{c}$ in diabetic patients at Tikur Anbessa specialized teaching hospital, Addis Ababa Ethiopia. BMC Hematol. 2019; 19:2. https://doi.org/10.1186/s12878-018-0132-1.

13. Hong JW, Ku CR, Noh JH, Ko KS, Rhee BD, Kim DJ. Association between the presence of iron deficiency anemia and hemoglobin A1c in Korean adults: the 2011-2012 Korea National Health and Nutrition Examination Survey. Medicine (Baltimore). 2015; 94(20):e825. https://doi.org/10.1097/MD.0000000000000825.

14. Rajagopal L, Ganapathy S, Arunachalam S, Raja V, Ramraj B. Does iron deficiency Anaemia and its severity influence $\mathrm{HbA1C}$ level in non diabetics? An analysis of 150 cases. J Clin Diagn Res. 2017; 11(2):EC13-5. https://doi.org/10.7860/ JCDR/2017/25183.9464.
15. Oatley H, Borkhoff CM, Chen S, Macarthur C, Persaud N, Birken CS, et al. Screening for iron deficiency in early childhood using serum ferritin in the primary care setting. Pediatrics. 2018; 142(6):e20182095. https://doi.org/10.1542/ peds.2018-2095.

16. Roganović J, Starinac K. Iron Deficiency Anemia in Children. In: Khan J. Current Topics in Anemia. Intech Open; 2018. https://doi.org/10.5772/intechopen.69774.

17. Short MW, Domagalski JE. Iron deficiency anemia: evaluation and management. Am Fam Physician. 2013; 87(2):98-104.

18. Kliegman RM. Nelson Textbook of Pediatrics. $20^{\text {th }}$ ed. Philadelphia: Elsevier; 2016. P. 298.

19. Fareeq $\mathrm{ZH}$, Zangana $\mathrm{KO}$. Influence of iron deficiency anemia on growth: A cross-sectional study. Med J Babylon. 2019; 16:335-9. https://doi.org/10.4103/mibl.mjbl 6119.

20. Ahmed A, Al-Rabaty A, Alnakshabandi A. Relationship Between Hemoglobin Level and Feeding Pattern in Apparently Healthy Children Below Two Years. Zanco J Med Sci. 2010; 14(1):9-15. https://zjms.hmu.edu.krd/index.php/ zims/article/view/485,

21. Dean L. Blood Groups and Red Cell Antigens. Bethesda (MD): National Center for Biotechnology Information (US); 2005. Table 1, Complete blood count. https://www.ncbi.nlm. nih.gov/books/NBK2263/table/ch1.T1/.

22. Soldin OP, Bierbower LH, Choi JJ, Choi JJ, Thompson-Hoffman S, Soldin SJ. Serum iron, ferritin, transferrin, total iron binding capacity, hs-CRP, LDL cholesterol and magnesium in children; new reference intervals using the Dade Dimension Clinical Chemistry System. Clin Chim Acta 2004; 342(1-2):211-7. https://doi.org/10.1016/j.cccn.2004.01.002.

23. Gallagher EJ, Le Roith D, Bloomgarden Z. Review of hemoglobin $A(1 c)$ in the management of diabetes. J Diabetes. 2009; 1(1):9-17. https://doi.org/10.1111/i.1753-0407.2009.00009.x.

24. Sinha N, Mishra TK, Singh T, Gupta N. Effect of iron deficiency anemia on hemoglobin A1C levels. Ann Lab Med. 2012; 32(1):17-22. https://doi.org/10.3343/alm.2012.32.1.17. 